\title{
Nutritional and Antioxidant Potential of Rice Flour Enriched with Kersting's Groundnut (Kerstingiella geocarpa) and Lemon Pomace
}

\author{
Olugbenga O. Awolu ${ }^{\mathrm{a}}$ And Magoh A. Osigwe \\ ${ }^{\mathrm{a}}$ Department of Food Science and Technology, Federal University of Technology, P.M.B 704, Akure, Ondo \\ State, Nigeria \\ * Corresponding author \\ ooawolu@futa.edu.ng
}

Received: 6 December 2017; Published online: 18 April 2019

\begin{abstract}
This study was designed to enhance the nutritional quality, antioxidant properties and product utilization potentials of locally produced 'Igbemo' rice flour by adding Kersting's groundnut and lemon pomace. Kersting's groundnut is an underutilized legume while lemon pomace is a byproduct of lemon utilization; both meant to enhance the protein quality, antioxidant potential and fibre contents of the composite flour. The dependent variables were minerals composition, amino acid profile, antioxidants and antinutrients properties, in-vitro protein digestibility and in-vitro carbohydrate digestibility. The result showed that blends with higher lemon pomace of $10.00 \mathrm{~g}$ had the best calcium, iron, potassium and magnesium contents and antioxidant contents, while blends with highest Kersting's groundnut $(20.00 \mathrm{~g})$ had the best zinc content. The anti-nutrients in the blends were generally low and safe for consumption.
\end{abstract}

Keywords: Antioxidants; Composite flour; Kersting's groundnut; Response surface methodology; Rice flour

\section{Introduction}

The increase in production and consumers' acceptability of rice flour in the production of nongluten baked products is promoting further research into rice flour utilization. In addition to its non-gluten characteristics, rice flour has been found to possess good nutritional qualities. Rice, as a cereal, serves as a basic food source for over half the world population whilst it provides about $80 \%$ of the food intake as readyto-eat convenience and inexpensive gluten-free snacks (Awolu, Oluwaferanmi, Fafowora, \& Oseyemi, 2015). Nutritionally, cereals are important sources of carbohydrates, dietary fibre and vitamins (Katina et al., 2005) but they are defi- cient in lysine. Cereal-based flours are therefore supplemented with legumes as credible source of lysine (Awolu et al., 2015; Awolu, Omoba, Olawoye, \& Dairo, 2017). In addition, legumes serve as sources of protein and minerals needed for health growth and development.

Kersting's groundnut (Kerstigiella geocarpa Harms) is an underutilized legume; it is rich in essential minerals, protein and amino acids. The crop is indigenous to Africa and a viable alternative to high protein content foods (Bayorbor, Dzomeku, Avornyo, \& Opoku-Agyeman, 2010). Kersting's groundnut has not been fully exploited and its nutritional importance has not been fully evaluated.

Lemon (Citrus limon) comes after orange and 
mandarin in the order of citrus importance. It is rich in vitamin $\mathrm{C}$, minerals, dietary fibre, essential oils, organic acids, carotenoids and flavonoids (Gonzalez-Molina, Dominguez-Perles, Moreno, \& Garcia-Viguera, 2010).

This study produced composite flour comprising rice, Kersting's groundnut and lemon pomace. The addition of Kersting's groundnut was meant to enhance its protein content and mineral compositions, whilst lemon pomace enhanced its fibre contents. Kersting's groundnut and lemon pomace has been found to be rich in antioxidants, hence, it was expected that their addition would enhance the antioxidant capacities of the composite flour.

\section{Materials and Methods}

\section{$2.1 \quad$ Materials}

Igbemo rice was sourced from Igbemo-Ekiti, Ekiti State. Kersting's groundnut (Kerstingiella geocarpa Harms.) was sourced from Oyingbo market, Lagos. Lemon fruits were sourced at Oja-Oba, Akure, Ondo State. All reagents were of analytical grade.

\section{$2.2 \quad$ Preparation of Flours}

\section{Preparation of rice flour}

About $5 \mathrm{~g}$ of Igbemo' rice grains were manually cleaned, dry-milled using hammer mill, sieved through $210 \mu \mathrm{m}$ particle size sieves and then stored in a sealed plastic container at room temperature for further processing (Awolu et al., 2015).

\section{Preparation of Kersting's groundnut flour}

Kersting's groundnut seeds $(2.0 \mathrm{~kg})$ were parboiled for $35 \mathrm{~min}$, manually dehulled, oven dried at $65{ }^{\circ} \mathrm{C}$ until constant weight was obtained and hammer-milled into fine particles. The flour was subsequently kept inside a sealed plastic container prior to usage (Awolu et al., 2015).

\section{Preparation of lemon pomace flour}

Lemon pomace was produced according to the method described by Kolodziejczyk, Markowski, Kosmala, Król, and Plocharski (2007). Fresh lemon fruits were washed with warm water to remove tough dirt and dust from the fruits. The washed fruit was pulverized with a sharp knife and blended into slurry using a Kenwood blender (BL-237). The juice was extracted from the slurry using a muslin cloth whilst the wet lemon pomace was oven dried (Gen-lab hot air oven, model DHG-9101.1SA) at $60{ }^{\circ} \mathrm{C}$ for $18 \mathrm{~h}$. The dried pomace was blended into fine flour using the blender.

\subsection{Experimental design for the development of flour blends}

Optmization of the proximate properties of the composite flour was carried out using the optimal mixture model design of response surface methodology (Design expert 8.0.3.1, trial version). The independent variables were rice flour $(70.30-85.00 \%)$, Kersting's groundnut flour $(10.00-20.00 \%)$ and lemon pomace (5.00 $10.00 \%$ ) while the dependent variables were the proximate composition.

\subsection{Proximate composition determination of the composite flour}

The moisture content, crude protein, fat, ash content and crude fibre of the composite flour blends were determined according to the standard methods of AOAC (2005).

\subsection{Minerals analysis}

Mineral analysis was determined according to the AOAC (2005) method. The sample was ashed, and about $15 \mathrm{~mL}$ of $6 \mathrm{~N} \mathrm{HCl}$ was added to it and transferred to a $100 \mathrm{~mL}$ volumetric flask. Distilled water was used to make up to the $100 \mathrm{~mL}$ mark. Atomic Absorption Spectroscopy (AAS) was used for analysis of all the minerals except potassium and sodium which were analyzed using a flame emission spectrophotometer

\begin{tabular}{l|l|l|l} 
IJFS & April $2019 \mid$ Volume 8 & pages 30-40
\end{tabular} 
(Model A-6200, Shimadzu, Corporation and Kyoto, Japan). Standards for sodium and potassium were prepared from their chloride salts.

\subsection{Amino acid profile determination}

The sample was hydrolyzed using hydrochloric acid $(6 \mathrm{~N})$ for $24 \mathrm{~h}$ at $110{ }^{\circ} \mathrm{C}$ in a vial under vacuum and $\mathrm{N}_{2}$ atmosphere, evaporated and dissolved in sodium citrate buffer $(\mathrm{pH} 2.2)$ and the hydrolysates were analyzed by using a HPLC combined with a Pickering PCX5200 derivatizer (Pickering Laboratories, Inc., USA) and ion exchange column $(3.0 \times 250 \mathrm{~mm}, 8 \mu \mathrm{m})$. The amino acids were identified spectrophotometrically by measuring at $570 \mathrm{~nm}$ (Benitez, 1989).

\subsection{Evaluation of Antioxidants Properties}

\section{Determination of ABTS scavenging ability}

Aqueous 2, 2'-azino-bis (3-ethylbenthiazoline-6sulphonic acid) (ABTS) scavenging ability solution $(7.8 \mathrm{M})$ with $\mathrm{K}_{2} \mathrm{~S}_{2} \mathrm{O}_{8}(2.45 \mathrm{mM}$, final conc.) was left in the dark for $16 \mathrm{~h}$ and the absorbance adjusted at $734 \mathrm{~nm}$ to 0.700 with ethanol. About $0.2 \mathrm{~mL}$ of the appropriate dilution of the extract was added to $2.0 \mathrm{~mL}$ of ABTS solution and the absorbance was read at $732 \mathrm{~nm}$ after 15 min. The Trolox (6-hydroxy-2, 5, 7, 8tetramethylchromane-2-carboxylic acid) equivalent antioxidant capacity was subsequently calculated (Re et al., 1999).

\section{Determination of DPPH free radical scavenging ability}

The stock reagent solution $\left(1 \times 10^{-3} \mathrm{M}\right.$ was prepared by dissolving $22 \mathrm{mg}$ of DPPH in $50 \mathrm{~mL}$ of methanol and stored at $20{ }^{\circ} \mathrm{C}$. The working solution $\left(6 \times 10^{-5} \mathrm{M}\right)$ was prepared by mixing 6 $\mathrm{mL}$ of stock solution with $100 \mathrm{~mL}$ of methanol to obtain an absorbance value of $0.8 \pm 0.02$ at 515 $\mathrm{nm}$. Exactly $0.1 \mathrm{~mL}$ each of extract solutions of different concentrations were vortexed for $30 \mathrm{~s}$ with $3.9 \mathrm{~mL}$ of DPPH solution and left to react for $30 \mathrm{~min}$; the absorbance at $515 \mathrm{~nm}$ was then recorded. A control with no added extract was also analyzed. DPPH Scavenging activity was calculated using Eq. (1) (Lee, Mulugu, York, \& O'Shea, 2007).

$$
D P P H=\frac{A b_{\text {control }}-A b_{\text {sample }}}{A b_{\text {control }}} \times 100
$$

Where $\mathrm{Ab}=$ Absorbance

\section{Total flavonoids}

About $0.5 \mathrm{~mL}$ aliquot of $20 \mathrm{~g} \mathrm{~L}^{-1} \mathrm{AlCl}_{3}$ ethanolic solution was added to $0.5 \mathrm{~mL}$ of extract solution. The absorbance at $420 \mathrm{~nm}$ was measured after $1 \mathrm{~h}$ at room temperature. The presence of flavonoids was indicated by a yellow colouration. Extract samples were evaluated at a final concentration of $0.1 \mathrm{mg} \mathrm{mL}^{-1}$ (Eq. 2) and expressed as quercetin equivalent (QE) based on the calibration curve (Ordonez, Gomez, Vattuone, \& Lsla, 2006)

$$
C=0.00255 \times A b \quad\left(R^{2}=0.9812\right)
$$

Where $A b$ is the absorbance and $C$ is the concentration (mg QE g $\left.{ }^{-1} \mathrm{DW}\right)$

\subsection{Determination of Antinutrients}

\section{Determination of oxalate content}

About $1 \mathrm{~g}$ of sample was weighed into $100 \mathrm{~mL}$ conical flask, $75 \mathrm{~mL} 3 \mathrm{M} \mathrm{H}_{2} \mathrm{SO}_{4}$ was added and stirred for $1 \mathrm{~h}$ with a magnetic stirrer. Exactly $25 \mathrm{~mL}$ of the filtrate (Whatman filter paper No.1) was taken and titrated hot against $0.05 \mathrm{M}$ $\mathrm{KMnO}_{4}$ solution until a faint pink colour which persisted for at least $30 \mathrm{sec}$ was formed. The oxalate content was calculated by taking $1 \mathrm{~mL}$ of $0.05 \mathrm{M} \mathrm{KMnO}_{4}$ as equivalent to $2.2 \mathrm{mg}$ oxalate using Eq. (3) (Day \& Underwood, 1986)

$$
\text { Oxalate }(m g / 100 g)=\frac{\text { Titrevalue } \times 2.2 \times D F}{W}
$$

Where $2.2 \mathrm{mg}=$ mass equivalent value of $1 \mathrm{~mL}$ of $0.05 \mathrm{M} \mathrm{KMnO}_{4}$ solution.

$\mathrm{DF}=$ Dilution factor (total volume of sample divided by volume of portion used for titration) ${ }^{*} \mathrm{~W}=$ Sample weight in $\mathrm{g}$.

$$
\text { IJFS | April } 2019 \text { | Volume } 8 \text { | pages 30-40 }
$$




\section{Determination of phytic acid content}

About $2 \mathrm{~g}$ of sample was weighed into $250 \mathrm{~mL}$ conical flask; $100 \mathrm{~mL}$ of $2 \%$ concentrated $\mathrm{HCl}$ was thereafter added, allowed to soak for $3 \mathrm{~h}$ and filtered. The filtrate $(50 \mathrm{~mL})$ was pipetted into $250 \mathrm{~mL}$ beaker, with $107 \mathrm{~mL}$ ammonium thiocyanate solution added as an indicator and titrated with standard iron III chloride $\mathrm{FeCl}_{3}$ solution (containing $0.00195 \mathrm{~g}$ iron/mL) until a brownish yellow colour appeared and persisted for five minutes. The phytic acid content was calculated using Eq. (4) (Russell, 1980):

$$
P H Y=\frac{0.00195 \times V_{\mathrm{FeCl}_{3}} \times D F}{W_{\text {Sample }}}
$$

$\mathrm{PHY}=$ Phyticacid $(\mathrm{g} / \mathrm{kg})$

$V_{\mathrm{FeCl}_{3}}=$ volume of $\mathrm{FeCl}_{3}$ consumed

$W_{\text {Sample }}=$ sample weight

$\mathrm{DF}=$ Total volume of extraction solvent added/volume of aliquot taken for the titration.

\section{Determination of tannin content}

About $0.2 \mathrm{~g}$ of sample was placed in a test tube, $10 \mathrm{~mL}$ of $1 \% \mathrm{HCl} /$ methanol was added, the test tube was capped, continuously shaken for $20 \mathrm{~min}$ and then centrifuged at $2500 \mathrm{rpm}$ for $5 \mathrm{~min}$. Exactly $1 \mathrm{~mL}$ of the supernatant was pipetted into fresh tubes, the absorbance was set at zero and $1 \mathrm{~mL}$ blank solution was mixed with $5 \mathrm{~mL} 4 \%$ $\mathrm{HCl} /$ methanol and $5 \mathrm{~mL}$ vanillin reagent in a test tube. The sample and blank test tubes were incubated for $20 \mathrm{~min}$ at $30{ }^{\circ} \mathrm{C}$. Absorbance was read at $500 \mathrm{~nm}$ and concentration of condensed tannins was determined from standard curve. Tannin concentration was expressed in $\%$ as follows (Trease \& Evans, 1978):

$$
\text { Tannic content }=\frac{(C \times 10)}{200} \times 100
$$

Where:

$\mathrm{C}=$ Concentration corresponding to the optical density

$10=$ Volume of extract $(\mathrm{mL})$

$200=$ sample weight $(\mathrm{mg})$

\section{Determination of saponin content}

About $20 \mathrm{~mL}$ of $20 \%$ aqueous ethanol was added to $10 \mathrm{~g}$ of the ground sample and agitated with a magnetic stirrer for $12 \mathrm{~h}$ at $55{ }^{\circ} \mathrm{C}$. The solution was filtered through Whatman No.1 filter paper and the residue re-extracted with $200 \mathrm{~mL}$ $20 \%$ aqueous ethanol. The extract was reduced to $40 \mathrm{~mL}$ under vacuum and $20 \mathrm{~mL}$ diethyl ether added in a separating funnel and shaken vigorously. The aqueous layer was recovered while the ether layer was discarded. The $\mathrm{pH}$ of the aqueous solution was adjusted to 4.5 by adding $\mathrm{NaOH}$, and the solution shaken with $60 \mathrm{ml} \mathrm{n-}$ butanol. The combined butanol extracts were washed twice with $10 \mathrm{~mL}$ of $5 \%$ aqueous $\mathrm{NaCl}$ and evaporated to dryness in a fume cupboard to give a crude saponin (Hudson \& El-Difrawi, 1979).

\section{Determination of trypsin inhibitor}

Tris-buffer (0.05 M, pH 8.2) containing 0.02 $\mathrm{M} \mathrm{CaCl}_{2}: \quad 6.05 \mathrm{~g}$ tris- (hydroxymethyl) aminomethane and $2.94 \mathrm{~g} \mathrm{CaCl}_{2} \cdot 2 \mathrm{H}_{2} \mathrm{O}$ were dissolved in $500 \mathrm{~mL}$ of distilled water, the $\mathrm{pH}$ was adjusted to 8.2 and the volume made up to $1 \mathrm{~L}$ with distilled water. About $2.0 \mathrm{~mL}$ of trypsin solution was added to $1.0 \mathrm{~g}$ of the extracted sample in a test tube and then placed in a water bath at $37{ }^{\circ} \mathrm{C}$. Exactly $5 \mathrm{~mL}$ hydrated Benzoyl-DLarginene-p-nutoanilide (BAPA) solution was dissolved in dimethyl sulfoxide previously warmed to $37^{\circ} \mathrm{C}$. The reaction was terminated $10 \mathrm{~min}$ later by adding $1 \mathrm{~mL}$ of $30 \%$ acetic acid. After thorough mixing, the contents of each tube were filtered through Whatman No.1 paper and the absorbance was measured against the blank (Kakade, 1974).

\subsection{In-vitro protein (IVPD) determination}

Composite flour samples (200 mg) were weighed into an Erlenmeyer flask and mixed with 35 $\mathrm{mL}$ of porcine pepsin $(1.5 \mathrm{~g}$ of pepsin in $0.1 \mathrm{M}$ $\mathrm{KH}_{2} \mathrm{PO}_{4}, \mathrm{pH} 2.0$ ). Samples were digested for 2 $\mathrm{h}$ at $37^{\circ} \mathrm{C}$; digestion was stopped by addition of $2 \mathrm{~mL}$ of $2 \mathrm{M} \mathrm{NaOH}$ and the samples were centrifuged $\left(4900 \mathrm{xg}\right.$ at $40{ }^{\circ} \mathrm{C}$ ) for $20 \mathrm{~min}$ after 
which the supernatant was discarded. The residues were washed and centrifuged twice with $20 \mathrm{~mL}$ of buffer $\left(0.1 \mathrm{M} \mathrm{KK_{2 }} \mathrm{PO}_{4}, \mathrm{pH}\right.$ 7.0). Undigested nitrogen was determined using Kjeldahl method. Digestibility was calculated using Eq. (6) (Aboubacar, Axtell, Huang, \& Hamaker, 2001).

$$
I V P D=\frac{\left(N_{\text {sample }}-N_{\text {Undigested }}\right)}{N_{\text {sample }}} \times 100
$$

\subsection{In-vitro carbohydrate digestibility determination (IVCD)}

Exactly $4 \mathrm{~mL}$ of phosphate buffer ( $\mathrm{pH}$ 6.6), 1 $\mathrm{mL}$ of sodium chloride and $1 \mathrm{~mL}$ of $\alpha$ amylase enzyme was added to $5 \mathrm{~mL}$ of the sample at room temperature and mixed thoroughly. Aliquots $(0.2 \mathrm{~mL})$ of the mixture were taken at zero and $1.0 \mathrm{~h}$ (complete hydrolysis was predetermined) after addition of the enzyme and dispensed into $10 \mathrm{~mL}$ Lugol's iodine solution (1:100 dilution). The absorbance was measured at $620 \mathrm{~nm}$ and the in- vitro carbohydrate digestibility was calculated using Eq. (7) (Shekib, Eliraqui, \& Abobakr, 1988).

$$
I V C D=\frac{A b s_{\text {time }=0}-A b s_{\text {time }}=1 \mathrm{~h}}{A b s_{\text {time }}=0} \times 100
$$

where Abs is the Absorbance

\section{Results and Discussions}

\subsection{Proximate composition and functional properties of the composite flour}

The result of the proximate composition is presented in Table 1. The moisture content of the composite flour (6.20 to $6.81 \mathrm{~g} / 100 \mathrm{~g}$ ) was within the acceptable range $(\leq 10 \%)$ for flours to ensure shelf stability. In addition, the variation in moisture content of the composite flour had a low R-squared and the adjusted R-squared values of 0.3496 and 0.0244 respectively, which was an indication that it would not support moisture; hence, the composite flour would have a good shelf life.

The ash content of the composite flour ranged between 0.98 and $1.81 \mathrm{~g} / 100 \mathrm{~g}$. The ash content increased significantly $(\mathrm{p} \leq 0.05)$ as the levels of lemon pomace incorporation increased. The $\mathrm{R}$-squared and adjusted R-squared values were 0.7546 and 0.7168 respectively. The crude protein of the flour samples ranged between 7.51 and $12.99 \mathrm{~g} / 100 \mathrm{~g}$. The protein content increased significantly $(\mathrm{p} \leq 0.05)$ as the level of Kersting's groundnut incorporation increased. A similar results have been obtained for composite flour consisting of rice, cassava and Kersting's groundnut flours (Awolu et al., 2015). The ANOVA indicated that the model and model term (linear mixture, $\mathrm{AB}, \mathrm{AB}(\mathrm{A}-\mathrm{B}))$ were significant $(\mathrm{p} \leq 0.05)$ while the R-squared and the adjusted R-squared values were 0.9975 and 0.9937 respectively. The high adjusted R-squared value for protein content showed that the protein had high positive effect on the composite flour.

The fat content of the flours ranged from 4.00 - $4.44 \mathrm{~g} / 100 \mathrm{~g}$. In comparison, wheat flour had fat content of $1.33 \mathrm{~g} / 100 \mathrm{~g}$. The fat content decreased with increased incorporation of rice and lemon pomace flours. The composite flour may be better enhancer of flavour and fat-soluble vitamins than wheat flour. In addition, the fat values of the composite flour should not possess any negative effect in terms of rancidity. The crude fibre values ranged from 2.52 to 3.78 $\mathrm{g} / 100 \mathrm{~g}$. The result indicated that the addition of Kersting's groundnut flour and lemon pomace increased the crude fibre content of the composite flour. The ANOVA indicated that the model and model terms (linear mixture, $\mathrm{AB}, \mathrm{AB}(\mathrm{A}-\mathrm{B})$ for crude fibre were significant $(\mathrm{p} \leq 0.05)$ while the $\mathrm{R}$-squared and adjusted R-squared were 0.9975 and 0.9937 respectively.

The carbohydrates content of the flours ranged between $62.03-72.98 \mathrm{~g} / 100 \mathrm{~g}$. The model and model terms (linear mixture component, $\mathrm{AB}$, $\left.\mathrm{AC}, \mathrm{A}^{2} \mathrm{BC}, \mathrm{ABC}^{2}\right)$ were significant $(\mathrm{p} \leq 0.05)$ while the $\mathrm{R}$-squared and adjusted R-squared were 0.9945 and 0.9882 respectively. 
Antioxidants Potential of Enriched Rice Flour $\mid 35$

Table 1: Proximate Composition of Composite Flour

\begin{tabular}{lccccccccc}
\hline & \multicolumn{3}{c}{ Variables $(\mathrm{g})$} & \multicolumn{5}{c}{ Proximate composition (g/100g) } \\
Run & $\mathrm{A}(\mathrm{g})$ & $\mathrm{B}(\mathrm{g})$ & $\mathrm{C}(\mathrm{g})$ & Moisture & Ash & Protein & Fibre & Fat & CHO \\
\hline 1 & 79.84 & 10.16 & 10.00 & 6.40 & 1.81 & 7.51 & 3.71 & 4.00 & 66.57 \\
2 & 75.00 & 20.00 & 5.00 & 6.20 & 1.25 & 12.99 & 2.89 & 4.28 & 67.39 \\
3 & 83.50 & 11.50 & 5.00 & 6.50 & 1.05 & 8.56 & 2.80 & 4.00 & 72.09 \\
4 & 70.30 & 20.00 & 9.70 & 6.30 & 1.76 & 12.57 & 3.34 & 4.30 & 62.03 \\
5 & 76.98 & 15.75 & 7.25 & 6.46 & 1.70 & 9.12 & 3.21 & 4.27 & 67.98 \\
6 & 79.84 & 10.16 & 10.00 & 6.47 & 1.30 & 8.43 & 3.62 & 4.00 & 66.18 \\
7 & 82.28 & 10.00 & 7.71 & 6.30 & 1.48 & 8.41 & 3.70 & 4.00 & 68.40 \\
8 & 75.00 & 20.00 & 5.00 & 6.81 & 1.30 & 12.8 & 2.90 & 4.44 & 66.75 \\
9 & 85.00 & 10.00 & 5.00 & 6.40 & 0.98 & 8.41 & 2.68 & 4.01 & 72.52 \\
10 & 73.16 & 19.07 & 7.76 & 6.62 & 1.68 & 12.72 & 3.18 & 4.36 & 63.67 \\
11 & 82.28 & 10.00 & 7.71 & 6.80 & 1.60 & 8.46 & 3.72 & 4.11 & 67.60 \\
12 & 85.00 & 10.00 & 5.00 & 6.41 & 1.06 & 7.99 & 2.66 & 4.00 & 72.88 \\
13 & 80.31 & 14.68 & 5.00 & 6.43 & 1.32 & 9.55 & 2.52 & 4.20 & 70.98 \\
14 & 77.44 & 12.55 & 10.00 & 6.41 & 1.80 & 9.00 & 3.78 & 4.10 & 64.91 \\
15 & 73.56 & 16.43 & 9.99 & 6.30 & 1.74 & 11.62 & 3.09 & 4.19 & 63.10 \\
16 & 70.30 & 20.00 & 9.70 & 6.30 & 1.76 & 12.63 & 3.30 & 4.24 & 62.07 \\
\hline
\end{tabular}

*A - Rice Flour; B - Kersting's groundnut; C- Lemon pomace; CHO - Carbohydrate

\subsection{Minerals composition of optimized composite flour}

The result of the mineral composition of the composite flour is presented in Table 2. Iron contents in the composite flour ranged between 2.82 and $3.47 \mathrm{mg} / 100 \mathrm{~g}$. Iron deficiency is the most common nutrient disorder worldwide as it accounts for $50 \%$ of the cases of anaemia (World Health Organization, 2001). Iron contents reported in rice, Kersting's groundnut and lemon pomace flours were $0.82 \mathrm{mg} / 100 \mathrm{~g}$, $10.00 \mathrm{mg} / 100 \mathrm{~g}$ and $147.65 \mathrm{mg} / 100 \mathrm{~g}$ respectively (Adeyeye \& Faleye, 2007; Atukorale, 2002; Janati, Beheshti, Feizy, \& Fahim, 2012). The iron content in composite flour increased significantly $(\mathrm{p} \leq 0.05)$ as the level of lemon pomace increased.

Zinc values ranged from 2.37 to $2.67 \mathrm{mg} / 100 \mathrm{~g}$. Zinc content in the composite flour increased significantly $(\mathrm{p} \leq 0.05)$ as the levels of Kersting's groundnut increased. The values of zinc obtained in this study was higher than $0.58-0.66 \mathrm{mg} / 100 \mathrm{~g}$ reported for wheat based composite flour enriched with 'orarudi' (Vahigna sp) (Onoja et al., 2014).

Magnesium values ranged between 4.54 and 4.64 $\mathrm{mg} / 100 \mathrm{~g}$. The magnesium content increased significantly $(\mathrm{p} \leq 0.05)$ as the lemon pomace increased. Magnesium is a cofactor in about 300 enzyme systems which play regulatory roles in several biochemical reactions in the body such as protein synthesis, muscle and nerve function, blood glucose control and blood pressure regulation (Laurant \& Touyz, 2000). It also promotes strong bones strong and keeps heart rhythm steady (Twum et al., 2015).

Potassium ranged between 121.77 -166.33 mg/100g. Potassium content increased significantly $(\mathrm{p} \leq 0.05)$ with increasing lemon pomace flour content. Potassium plays a vital role in maintaining osmotic balance and $\mathrm{pH}$ of the body fluids, regulating muscle and nerve irritability, controlling glucose absorption and enhancing normal retention of protein during growth (National Research Council, 1980).

Calcium values ranged from 55.65 to 65.10 $\mathrm{mg} / 100 \mathrm{~g}$. Lemon pomace had been reported to contain about $8452.50 \mathrm{mg} / 100 \mathrm{~g}$ calcium content (Janati et al., 2012). The calcium content of 
the composite flour increased significantly ( $p$ $\leq 0.05)$ as lemon pomace increased. Calcium functions primarily in the development of strong bones.

\subsection{Antioxidant properties of the composite flour}

The results of the antioxidant property of composite flour are presented in Table 3. The DPPH free radical scavenging ability ranged from 39.57 to $45.10 \%$. DPPH of the composite flour increased significantly $(\mathrm{p} \leq 0.05)$ as lemon pomace increased.

The ABTS scavenging ability of the composite flour ranged between 23.81 and $25.40 \mathrm{mMol} / \mathrm{g}$. The ABTS also increased significantly $(\mathrm{p} \leq 0.05)$ as lemon pomace increased. The increase in both DPPH scavenging activities and ABTS as a result of the addition of lemon pomace is a justification for its addition, which is to improve antioxidant capacities. In addition, lemon pomace flour had positive effect on the flavonoids content of the composite flour; an increase in level of lemon pomace in the composite flour brought about a corresponding significant $(\mathrm{p} \leq 0.05)$ increase in the flavonoid contents. Flavonoids are major polyphenolic components of foods and display anti-inflammatory, anti-allergic and anti-cancer activities (Crozier, Clifford, \& Ashihara, 2008).

\section{Antinutritional properties of composite flour}

The results of antinutritional properties of the composite flour are presented in Table 4. Phytate content of the composite flour ranged between 2.29 and $2.50 \mathrm{mg} / 100 \mathrm{~g}$. Run 2 with the highest Kersting's groundnut content $(20 \mathrm{~g} / 100 \mathrm{~g})$ had the overall highest antinutrients contents. However, the antinutrients contents were within recommended level that is safe for human consumption; the recommended toxicity level of phytates for humans is $2-5 \mathrm{~g}$ /day (Hassan, Umar, \& Umar, 2004), while the phytate content in the composite flour was far less than this value.

There was no significant ( $p>0.05$ ) difference between the tannin contents of the composite flour of the samples. The tannin content obtained in this study was also very safe for consumption (Ikpeme, Ekpeyoung, \& Igile, 2012). This low result indicated that the composite flour would have good protein digestibility as high protein contents interferes with protein digestibility.

The trypsin inhibitor activity of the composite flour ranged between 0.26 and $0.34 \mathrm{mg} / 100 \mathrm{~g}$. The higher the Kersting's groundnut content, the higher the trypsin inhibition activity. As with already mentioned antinutrients, the trypsin inhibition levels were very minimal and safe for human consumption. A trypsin inhibitor activity content ranging from 4.01 to $46.01 \mathrm{mg} / 100 \mathrm{~g}$ has been reported for Acha-Soybean composite flour (Ikpeme et al., 2012).

Oxalates ranged from 0.73 to $0.87 \mathrm{mg} / \mathrm{g}$. The level of oxalate obtained is also low and safe for human consumption. The toxicity of oxalates is $2-5 \mathrm{~g}$ /day (Hassan et al., 2004). The saponin content obtained in this study was also low and safe for human consumption.

\section{In-vitro carbohydrate digestibility and in-vitro protein digestibility of the composite flour}

Research has shown that nutrient composition of foods is not enough to determine nutrient bio-availability (Julian et al., 2007), hence the need for in-vitro (starch and protein) digestibility analyses. The result of in-vitro carbohydrate digestibility is presented in Table 5 . The results showed that the sample with highest rice content (run 7) had the overall best carbohydrate digestibility. Rice content dictates the extent of the carbohydrate digestibility; the higher the rice content the higher the carbohydrate digestibility and vice versa. In addition, digestion time rather than digestion temperature enhanced carbohydrate digestibility. Carbohydrate digestibility was higher in samples with the same digestion temperature but higher digestion time; hence digestion at 60 min was higher than digestion at $30 \mathrm{~min}$.

The results of in-vitro protein digestibility are presented in Table 6 . Unlike carbohydrate digestibility where the sample with the highest rice (with highest carbohydrate content) had the highest digestibility, protein digestibility had the 
Antioxidants Potential of Enriched Rice Flour $\mid 37$

Table 2: Minerals Composition of the Composite Flour

\begin{tabular}{lccccc}
\hline Sample & $\begin{array}{c}\text { Calcium } \\
(\mathrm{mg} / 100 \mathrm{~g})\end{array}$ & $\begin{array}{c}\text { Potassium } \\
(\mathrm{mg} / 100 \mathrm{~g})\end{array}$ & $\begin{array}{c}\text { Zinc } \\
(\mathrm{mg} / 100 \mathrm{~g})\end{array}$ & $\begin{array}{c}\text { Iron } \\
(\mathrm{mg} / 100 \mathrm{~g})\end{array}$ & $\begin{array}{c}\text { Magnesium } \\
(\mathrm{mg} / 100 \mathrm{~g})\end{array}$ \\
\hline Runs 2 & $55.65 \pm 1.21^{c}$ & $121.77 \pm 0.59^{c}$ & $2.67 \pm 0.05^{a}$ & $2.82 \pm 0.11^{b}$ & $4.54 \pm 0.12^{c}$ \\
Runs 7 & $61.11 \pm 1.18^{b}$ & $139.00 \pm 0.58^{b}$ & $2.55 \pm 0.10^{a}$ & $3.33 \pm 0.14^{a}$ & $4.58 \pm 0.18^{b}$ \\
Runs 14 & $65.10 \pm 0.96^{a}$ & $166.33 \pm 0.58^{a}$ & $2.37 \pm 0.05^{b}$ & $3.47 \pm 0.08^{a}$ & $4.64 \pm 0.12^{a}$ \\
\hline
\end{tabular}

*values are mean \pm standard deviation of triplicate samples

*values on the same column with the same superscript are not significantly different at $\mathrm{p} \leq 0.05$

$*_{\text {Run }} 2=75 \mathrm{~g} / 100 \mathrm{~g}$ rice; $20 \mathrm{~g} / 100 \mathrm{~g}$ Kersting's groundnut, $5 \mathrm{~g} / 100 \mathrm{~g}$ lemon pomace flours

*Run $7=82.28 \mathrm{~g} / 100 \mathrm{~g}$ rice; $10 \mathrm{~g} / 100 \mathrm{~g}$ Kersting's groundnut, $7.71 \mathrm{~g} / 100 \mathrm{~g}$ lemon pomace flours

*Run $14=77.44 \mathrm{~g} / 100 \mathrm{~g}$ rice; $12.55 \mathrm{~g} / 100 \mathrm{~g}$ Kersting's groundnut, $10 \mathrm{~g} / 100 \mathrm{~g}$ lemon pomace flours

Table 3: Antioxidant Properties of the Composite Flour

\begin{tabular}{lccc}
\hline Sample & DPPH (\%) & ABTS $(\mathrm{mMol} / \mathrm{g})$ & Flavonoids $\left(\mathrm{mg} \mathrm{QE} \mathrm{g}^{-1}\right)$ \\
\hline Runs 2 & $39.57 \pm 1.35^{c}$ & $23.81 \pm 0.08^{c}$ & $1.21 \pm 0.01^{c}$ \\
Runs 7 & $42.73 \pm 3.05^{a b}$ & $24.40 \pm 0.40^{b}$ & $1.28 \pm 0.01^{a}$ \\
Runs 14 & $45.10 \pm 1.89^{a}$ & $25.40 \pm 0.24^{a}$ & $1.26 \pm 0.01^{b}$ \\
\hline
\end{tabular}

*values are mean \pm standard deviation of triplicate samples

*values on the same column with the same superscript are not significantly different at $\mathrm{p} \leq 0.05$

*Run $2=75 \mathrm{~g} / 100 \mathrm{~g}$ rice; $20 \mathrm{~g} / 100 \mathrm{~g}$ Kersting's groundnut, $5 \mathrm{~g} / 100 \mathrm{~g}$ lemon pomace flours

Run $7=82.28 \mathrm{~g} / 100 \mathrm{~g}$ rice; $10 \mathrm{~g} / 100 \mathrm{~g}$ Kersting's groundnut, $7.71 \mathrm{~g} / 100 \mathrm{~g}$ lemon pomace flours

*Run $14=77.44 \mathrm{~g} / 100 \mathrm{~g}$ rice; $12.55 \mathrm{~g} / 100 \mathrm{~g}$ Kersting's groundnut, $10 \mathrm{~g} / 100 \mathrm{~g}$ lemon pomace flours

Table 4: Antinutritional Properties of the Composite Flour

\begin{tabular}{lccccc}
\hline Sample & $\begin{array}{c}\text { Oxalate } \\
(\mathrm{mg} / 100 \mathrm{~g})\end{array}$ & $\begin{array}{c}\text { Saponin } \\
(\%)\end{array}$ & $\begin{array}{c}\text { Tannin } \\
(\mathrm{mg} / 100 \mathrm{~g})\end{array}$ & $\begin{array}{c}\text { Phytates } \\
(\mathrm{mg} / 100 \mathrm{~g})\end{array}$ & $\begin{array}{c}\text { Trypsin } \\
(\%)\end{array}$ \\
\hline Runs 2 & $0.87 \pm 0.01^{a}$ & $3.31 \pm 0.20^{a}$ & $0.03 \pm 0.00^{a}$ & $25.05 \pm 0.02^{a}$ & $0.34 \pm 0.12^{a}$ \\
Runs 7 & $0.73 \pm 0.02^{c}$ & $2.82 \pm 0.04^{b}$ & $0.03 \pm 0.00^{a}$ & $24.03 \pm 0.02^{b}$ & $0.26 \pm 0.02^{c}$ \\
Runs 14 & $0.81 \pm 0.04^{b}$ & $2.44 \pm 0.01^{c}$ & $0.03 \pm 0.00^{a}$ & $22.89 \pm 0.01^{c}$ & $0.27 \pm 0.04^{b}$ \\
\hline
\end{tabular}

*values are mean \pm standard deviation of triplicate samples *values on the same column with the same superscript are not significantly different at $\mathrm{p} \leq 0.05$

*Run $2=75 \mathrm{~g} / 100 \mathrm{~g}$ rice; $20 \mathrm{~g} / 100 \mathrm{~g}$ Kersting's groundnut, $5 \mathrm{~g} / 100 \mathrm{~g}$ lemon pomace flours

${ }^{*}$ Run $7=82.28 \mathrm{~g} / 100 \mathrm{~g}$ rice; $10 \mathrm{~g} / 100 \mathrm{~g}$ Kersting's groundnut, $7.71 \mathrm{~g} / 100 \mathrm{~g}$ lemon pomace flours

*Run $14=77.44 \mathrm{~g} / 100 \mathrm{~g}$ rice; $12.55 \mathrm{~g} / 100 \mathrm{~g}$ Kersting's groundnut, $10 \mathrm{~g} / 100 \mathrm{~g}$ lemon pomace flours

Table 5: In-vitro Carbohydrate Digestibility of Composite Flour

\begin{tabular}{lcccc}
\hline & \multicolumn{4}{c}{ Digested Starch } \\
\cline { 2 - 5 } Sample & $50^{\circ} \mathrm{C}$ for $60 \mathrm{~min}$ & $50^{\circ} \mathrm{C}$ for 30 min & $40^{\circ} \mathrm{C}$ for $60 \mathrm{~min}$ & $40^{\circ} \mathrm{C}$ for $30 \mathrm{~min}$ \\
\hline Run 2 & $28.67 \pm 0.80^{b}$ & $10.48 \pm 0.05^{c}$ & $25.47 \pm 0.12^{c}$ & $10.05 \pm 0.09^{c}$ \\
Run 7 & $30.00 \pm 0.45^{a}$ & $25.62 \pm 0.03^{a}$ & $28.44 \pm 0.42^{a}$ & $23.36 \pm 0.42^{a}$ \\
Run 14 & $28.54 \pm 0.02^{b}$ & $15.78 \pm 0.07^{b}$ & $27.88 \pm 0.11^{b}$ & $12.45 \pm 0.08^{b}$ \\
\hline
\end{tabular}

*values are mean \pm standard deviation of triplicate samples *values on the same column with the same superscript are not significantly differest at $\leq 0.05$

different at $\mathrm{p} \leq 0.05$
$*$ Run $2=75 \mathrm{~g} / 100 \mathrm{~g}$ rice; $20 \mathrm{~g} / 100 \mathrm{~g}$ Kersting's groundnut, $5 \mathrm{~g} / 100 \mathrm{~g}$ lemon pomace flours

$*$ Run $2=75 \mathrm{~g} / 100 \mathrm{~g}$ rice; $20 \mathrm{~g} / 100 \mathrm{~g}$ Kersting's groundnut, $5 \mathrm{~g} / 100 \mathrm{~g}$ lemon pomace flours
$*$ Run $7=82.28 \mathrm{~g} / 100 \mathrm{~g}$ rice; $10 \mathrm{~g} / 100 \mathrm{~g}$ Kersting's groundnut, $7.71 \mathrm{~g} / 100 \mathrm{~g}$ lemon pomace flours

$*$ Run $7=82.28 \mathrm{~g} / 100 \mathrm{~g}$ rice; $10 \mathrm{~g} / 100 \mathrm{~g}$ Kersting's groundnut, $7.71 \mathrm{~g} / 100 \mathrm{~g}$ lemon pomace flours
$*$ Run $14=77.44 \mathrm{~g} / 100 \mathrm{~g}$ rice; $12.55 \mathrm{~g} / 100 \mathrm{~g}$ Kersting's groundnut, $10 \mathrm{~g} / 100 \mathrm{~g}$ lemon pomace flours

\begin{tabular}{l|l|l|l} 
IJFS & April $2019 \mid$ Volume 8 & pages 30-40
\end{tabular} 
Table 6: In-vitro Protein Digestibility Determination (IVPD) of the Composite Flour

\begin{tabular}{lcc}
\hline Sample & \% Digestibility 10min & \% Digestibility $15 \mathrm{~min}$ \\
\hline Runs 2 & $69.26 \pm 0.01^{c}$ & $67.27 \pm 0.19^{c}$ \\
Runs 7 & $75.05 \pm 0.23^{b}$ & $73.78 \pm 0.48^{b}$ \\
Runs 14 & $77.59 \pm 0.04^{a}$ & $78.31 \pm 0.02^{a}$ \\
\hline
\end{tabular}

*values are mean \pm standard deviation of triplicate samples *values on the same column with the same superscript are not significantly different at $\mathrm{p} \leq 0.05$

*Run $2=75 \mathrm{~g} / 100 \mathrm{~g}$ rice; $20 \mathrm{~g} / 100 \mathrm{~g}$ Kersting's groundnut, $5 \mathrm{~g} / 100 \mathrm{~g}$ lemon pomace flours

*Run $7=82.28 \mathrm{~g} / 100 \mathrm{~g}$ rice; $10 \mathrm{~g} / 100 \mathrm{~g}$ Kersting's groundnut, $7.71 \mathrm{~g} / 100 \mathrm{~g}$ lemon pomace flours

*Run $14=77.44 \mathrm{~g} / 100 \mathrm{~g}$ rice; $12.55 \mathrm{~g} / 100 \mathrm{~g}$ Kersting's groundnut, $10 \mathrm{~g} / 100 \mathrm{~g}$ lemon pomace flours

Table 7: Amino Acid Profile of the Composite Flour

\begin{tabular}{cccc}
\hline $\begin{array}{c}\text { Essential } \\
\text { amino acid }\end{array}$ & $\begin{array}{c}\text { Concentration: } \\
\mathrm{g} / 100 \mathrm{~g} \text { protein }\end{array}$ & $\begin{array}{c}\text { Non-essential } \\
\text { amino acid }\end{array}$ & $\begin{array}{c}\text { Concentration: } \\
\mathrm{g} / 100 \mathrm{~g} \text { protein }\end{array}$ \\
\hline Leucine & 6.80 & Glycine & 3.89 \\
Lysine & 4.53 & Alanin & 4.09 \\
Isoleucine & 3.92 & Serine & 3.13 \\
Phenylalanine & 4.08 & Cystine & 1.21 \\
Valine & 3.97 & Aspartic acid & 7.01 \\
Methionine & 2.40 & Glutamic acid & 9.54 \\
Histidine & 2.55 & Proline & 2.84 \\
Threonine & 3.19 & Hydroxyproline & 5.76 \\
Tryptophan & 1.86 & Citrulline & 3.78 \\
& & Arginine & 2.55 \\
\hline
\end{tabular}

highest digestibility when Kersting's groundnut (main protein component) was only $12.55 \%$ of the composite flour. The effect of higher antinutrients (though at safe levels) in run 2 must have accounted for the lowest protein digestibility. In fact, run 2 with the highest protein content had the lowest protein digestibility. As with carbohydrate digestibility, the higher the digestion time the higher the digestibility.

\section{Amino acid profile of the composite flour}

The amino acid profile of the composite flour is presented in Table 7. Leucine was the highest (6.80 mg/100g) essential amino acid followed by lysine $(4.53 \mathrm{~g} / 100 \mathrm{~g})$. Lysine is a major limiting amino acid in cereals and the increase in lysine in the composite flour could be as a result of Kersting's groundnut incorporation. Lysine promotes protein synthesis and thus, it is important for growth and maintenance of the body (Awolu et al., 2017). Glutamic acid and aspartic acid were the most abundant amino acids in the composite flour with values of $9.54 \mathrm{~g} / 100 \mathrm{~g}$ and $7.01 \mathrm{~g} / 100 \mathrm{~g}$ respectively. Glycine, together with other essential amino acids such as alanine, arginine, and phenylalanine forms polypeptides that promote growth and tissue healing (Davies \& Reid, 1979).

\section{Conclusions}

The utilization of rice flour in the production of nutritionally rich baked products would be enhanced by the addition of Kersting's groundnut and lemon pomace. While Kersting's groundnut enhanced the protein content and minerals composition; lemon pomace enhanced its fibre content and antioxidant potentials. The addition of Kersting's groundnut at level of $20 \mathrm{~g} / 100 \mathrm{~g}$ of the composite flour was considered nutritionally safe.

\begin{tabular}{l|l|l|l} 
IJFS & April 2019 | Volume 8 & pages 30-40
\end{tabular} 
In essence, composite flour consisting rice, Kersting's groundnut and lemon pomace at the blend ratios carried out in this study would be beneficial for consumption in terms of its nutritional composition and antioxidant capacities without negative antinutritional factors.

\section{References}

Aboubacar, A., Axtell, J. D., Huang, C. P., \& Hamaker, B. R. (2001). A rapid protein digestibility assay for identifying highly digestible sorghum lines. Cereal Chemistry, 78(2), 160-165. doi:10 . 1094 / CCHEM . 2001.78.2.160

Adeyeye, E., \& Faleye, F. (2007). Chemical composition and the food properties of (kerstingiella geocarpa) harms seeds.

AOAC. (2005). Official methods of analysis. 15th edn. (Gaithersburg, S. edn). AOAC Press, Washington DC., USA. pp. 78- 90.

Atukorale, D. P. (2002). Nutritional value of rice. Daily News, March 1.

Awolu, O. O., Oluwaferanmi, P. M., Fafowora, O. I., \& Oseyemi, G. F. (2015). Optimization of the extrusion process for the production of ready-to-eat snack from rice, cassava and kersting's groundnut composite flours. LWT-Food Science and Technology, 64 (1), 18-24. doi:10.1016/j.lwt.2015. 05.025

Awolu, O. O., Omoba, O. S., Olawoye, O., \& Dairo, M. (2017). Optimization of production and quality evaluation of maizebased snack supplemented with soybean and tiger-nut (cyperus esculenta) flour. Food Science \& Nutrition, 5(1), 3-13. doi:10.1002/fsn3.359

Bayorbor, T., Dzomeku, I., Avornyo, V., \& Opoku-Agyeman, M. (2010). Morphological variation in kersting's groundnut (kerstigiella geocarpa harms) landraces from northern ghana. Agriculture and Biology Journal of North America, 1 (3), 290-295.

Benitez, L. V. (1989). Amino-acid and fatty-acid profiles in aquaculture nutrition studies. In S. S. Desilva (Ed.), Fish nutrition research in asia (Vol. 4, pp. 23-35). Asian Fisheries Society Special Publication. 3rd Asian
Fish Nutrition Network Meeting, Bangkok, Thailand, Jun 06-10, 1988. INT DEV RES CTR. Manila: Asian Fisheries Soc.

Crozier, A., Clifford, M. N., \& Ashihara, H. (2008). Plant secondary metabolites: Occurrence, structure and role in the human diet. John Wiley \& Sons.

Davies, N. T., \& Reid, H. (1979). An evaluation of the phytate, zinc, copper, iron and manganese contents of, and zn availability from, soya-based textured-vegetable-protein meat-substitutes or meat-extenders. British Journal of Nutrition, 41(3), 579589. doi:10.1079/BJN19790073

Day, R. A., \& Underwood, A. L. (1986). Quantitative analysis 5th edition laboratory manual. Includes bibliographical references and index. Englewood Cliffs, N.J.: PrenticeHall.

Gonzalez-Molina, E., Dominguez-Perles, R., Moreno, D. A., \& Garcia-Viguera, C. (2010). Natural bioactive compounds of citrus limon for food and health. Journal of Pharmaceutical and Biomedical Analysis, 51(2, SI), 327-345. doi:10.1016/j.jpba . 2009.07.027

Hassan, L. G., Umar, K. J., \& Umar, Z. (2004). Antinutritive factors in tribulus terrestris (linn.) leaves and predicted calcium and zinc bioavailability. Journal Tropical Bioscience, 7, 33-36.

Hudson, B. J. F., \& El-Difrawi, E. A. (1979). The sapogenins of the seeds of four lupin species. Journal of Plant Foods, 3(3), 181186. doi:10.1080/0142968X.1979.11904227

Ikpeme, C., Ekpeyoung, I., \& Igile, G. O. (2012). Nutritional and sensory characteristics of an infant food based on soybean seeds (glycine max) and tigernut tubers (cyperus esculenta). British Journal of Applied Science and Technology, 2(4), 356-366.

Janati, S. S. F., Beheshti, H. R., Feizy, J., \& Fahim, N. K. (2012). Chemical composition of lemon (Citrus limon) and peels its considerations as animal food. GIDA-Journal of Food, 37(5), 267-271.

Julian, A., G. I. O, B., Inyang, C., M. A., A., C. U., O., \& V. I., M. (2007). Protein dispersibility index and trypsin inhibitor activity of extruded blends of acha/aoybean: 
A response surface analysis. American Journal of Food Technology, 2(6), 502-511.

Kakade, M. L. (1974). Biochemical basis for the differences in plant protein utilization. Journal of Agricultural and Food Chemistry, 22(4), 550-555. doi:10.1021/ jf60194a014

Katina, K., Arendt, E., Liukkonen, K. H., Autio, K., Flander, L., \& Poutanen, K. (2005). Potential of sourdough for healthier cereal products. Trends in Food Science \& Technology, 16 (1-3), 104-112. 2nd International Symposium on Sourdough, Brussels, BELGIUM, OCT, 2003. doi:10.1016/j.tifs.2004. 03.008

Kolodziejczyk, K., Markowski, J., Kosmala, M., Król, B., \& Plocharski, W. (2007). Apple pomace as a potential source of nutraceutical products. Polish Journal of Food and Nutrition Sciences, 57(4), 291-295.

Laurant, P., \& Touyz, R. M. (2000). Physiological and pathophysiological role of magnesium in the cardiovascular system: Implications in hypertension. Journal of Hypertension, 18(9), 1177-1191. doi:10.1097/ 00004872-200018090-00003

Lee, Y.-S., Mulugu, S., York, J. D., \& O'Shea, E. K. (2007). Regulation of a cyclincdk-cdk inhibitor complex by inositol pyrophosphates. Science, 316(5821), 109112. doi: $10.1126 /$ science. 1139080

National Research Council. (1980). Drinking water and health: Volume 3. Washington, D.C.: National Academy Press.

Onoja, U., Akubor, P., Ivoke, N., I Atama, C., Onyishi, G., Felicia, E., ... Ejere, V. (2014). Nutritional composition, functional properties and sensory evaluation of breads based on blends of orarudi (vigna sp) and wheat flour. Scientific Research and Essays, 9(24), 1019-1026. doi:10.5897/ SRE2014.6104

Ordonez, A. A. L., Gomez, J. D., Vattuone, M. A., \& Lsla, M. I. (2006). Antioxidant activities of sechium edule (jacq.) swartz extracts. Food Chemistry, 97(3), 452-458.

Re, R., Pellegrini, N., Proteggente, A., Pannala, A., Yang, M., \& Rice-Evans, C. (1999). Antioxidant activity applying an improved abts radical cation decolorization assay. Free Radical Biology and Medicine, 26 (9-10), 1231-1237. doi:10.1016/S08915849(98)00315-3

Russell, J. A. (1980). A circumplex model of affect. Journal of Personality and Social Psychology, 39(6), 1161-1178. doi:10.1037 / h0077714

Shekib, L. A., Eliraqui, S. M., \& Abobakr, T. M. (1988). Studies on amylase inhibitors in some egyptian legume seeds. Plant Foods for Human Nutrition, 38(4), 325-332. doi:10.1007/BF01091730

Trease, G. E., \& Evans, W. C. (1978). A text book of pharmacognosy. 11ed.BailliereTindall, London.

Twum, L. A., Kottoh, I. D., Asare, I. K., Torgby-Tetteh, W., Buckman, E. S., \& Adu-Gyamfi, A. (2015). Physicochemical and elemental analyses of banana composite flour for infants. British Journal of Applied Science \&3 Technology, 6(3), 276-284.

World Health Organization. (2001). Iron deficiency anaemia: Assessment, prevention and control: A guide for programme managers. Geneva, WHO. 